\title{
A new pontoniine shrimp genus (Crustacea: Decapoda) from the Yemen, with a note on other species
}

\author{
A. J. BRUCE \\ Queensland Museum, P.O. Box 3300, South Brishane Queensland, \\ Australia 4101
}

(Accepted 15 Jamuary 1997)

An unusual new genus and species of coral inhabiting pontoniine shrimp from the Yemen is described and illustrated. The new shrimp is remarkable for its very small size and the unique form of its telson. Three other pontoniine shrimps are also reported from the Yemen for the first time, raising the number of such shrimp species known from southern Arabia to 18.

KeYwords: Crustacea, Decapoda, Palaemonidae, Pontoniinae, Yemenicaris trullicauda gen. nov., sp. nov., Indo-West Pacific, Yemen, coral associate.

\section{Introduction}

The caridean fauna of the southern Arabian peninsula has been little studied. Only 15 species of pontoniine shrimp have so far been reported, mostly common Indo-West Pacific species associated with branching corals. The first species recorded was Anchistus custos, from Loheia (Forsskål, 1775), the first pontoniine shrimp described from the Indo-West Pacific region. No further species were reported until Nobili (1906) recorded Periclimenella petitthouarsii from Perim. Kemp (1922) reported Harpiliopsis beaupresii from Aden and Calman (1939) described Periclimenaeus arabicus from the South Arabian Coast. Bruce (1969, 1971, 1978) recorded Palaemonella rotumana, Periclimenes elegans, P. grandis, $P$. diversipes, Harpiliopsis depressa and Jocaste lucina from Aden. More recently Holthuis (1986) added Conchodytes meleagrinae, Neoanchistus nasalis, Philarius gerlachei, Pontonia sibogae and Pontonia stylirostris from southern Oman. The present report adds four further species, collected during the University of York 1992 Expedition to the Yemen, Periclimenes obscurus Kemp, Coralliocaris viridis Bruce, Onycocaris sp., and a new genus and species, raising the total to a mere 18 species for this region. There is clearly much scope for further study of the caridean fauna of southern Arabia.

Carapace length (CL) refers to the postorbital carapace length. QM refers to the Queensland Museum, South Brisbane, and RMNH, to the National Natuurhistorisch Muscum, Leiden. 


\section{Class CRUSTACEA \\ Order DECAPODA \\ Suborder NATANTIA \\ Infraorder $C A R I D E A$ \\ Family PALAEMONIDAE \\ Subfamily Pontoniinae \\ Yemenicaris gen. nov.}

Diagnosis. Very small-sized shrimps of strongly depressed body form. Rostrum well-developed, compressed, dorsally dentate, lateral carinae obsolete. Carapace smooth, glabrous, inferior orbital angle distinct, supraorbital, epigastric and hepatic spines absent, antennal spine acute. Abdomen smooth, glabrous, third segment not posterodorsally produced, pleura all rounded. Telson far exceeding uropods, distally expanded, rounded, ventrally concave, with three pairs of dorsal spines, without posterior spines. Antennule normal, flagella short. Antenna with basicerite unarmed, scaphocerite well developed. Eye with globular cornea, peduncle with anterodorsal prominence. Epistome unarmed. Mandible slender, without palp, molar process feeble, incisor process well-developed, with numerous teeth; maxillula with feebly bilobed palp, laciniae slender; maxilla with short, simple non-setose palp, basal and coxal endites obsolete, scaphognathite broad; first maxilliped with feeble palp, basal endite broad, exopod with large caridean lobe, flagellum reduced, coxal endite fused with basal, epipod large, bilobed; second maxilliped with normal endopod, dactylar segment broad, exopod normal with plumose terminal setae, coxa not medially produced, epipod small, simple, without podobranch; third maxilliped with normal endopod, ischiomerus and basis fused, exopod normal with plumose terminal setac, coxa not medially produced, with oval lateral plate, without arthrobranch. Fourth thoracic sternite without median process, posterior sternites progressively broadening posteriorly, unarmed. First pereiopods slender, chela with simple fingers. Second pereiopods small, similar, unequal, fingers of major chela unarmed, dactylus closing into groove on fixed finger. Ambulatory pereiopods slender, dactyls simple, without basal process, distal corpus expanded. Appendix masculina short, multispinose. Uropod with protopod unarmed, exopod with small mobile distolateral spinule only.

Type species. Yemenicaris trullicauda sp. nov.

Systematic position. The new genus is most closely related to a group of genera in which the endite of the maxilla is obsolete and the exopod of the third maxilliped is normally developed: Exopontonia, Platycaris and Pliopontonia. The first genus has the propods of the ambulatory pereiopods with biunguiculate dactyls and the minor second pereiopod has the chela with a unique malleiform dactyl. Platycaris differs from Yemenicaris in the reduced, unarmed, laterally expanded rostrum, welldeveloped flagellum and small caridean lobe on the first maxilliped, the large, similar second perciopod chelae and stout ambulatory pereiopods. Yemenicaris is most closely related to Pliopontonia, which has closely similar mouthparts except for the more robust mandible, large simple epipod on the maxilla, and normal first maxilliped flagellum, and a similar dentate rostrum. Yemenicaris can be immediately distinguished from all three genera, and all other pontoniine genera, by its unusual telson, which is unique in the Palaemonidae, with its unusual length, extending well beyond the uropods, ventrally concave, rounded distal expansion, and lack of posterior spines. Yemenicaris also differs from these and most other pontoniine genera in the presence of angular tubercles on the anterodorsal aspect of the cyestalks. 
Etymology. From 'Yemen', the locality of capture, and caris (Latin, shrimp, from Greek, karis).

\section{Yemenicaris trullicauda sp. nov.}

(Figs 1-4)

Material examined. 1 ovig. ?, HoLoryPE, CL $1.67 \mathrm{~mm}$, stn 92Y3L, Khalf, Yemen, $14^{\circ} 35^{\prime} \mathrm{N} 49^{\circ} 10^{\prime} \mathrm{E}$, to $9 \mathrm{~m}, 4$ September 1992, QM W 21902. 1 ovig. dissected ParatyPe, CL $1.27 \mathrm{~mm}$, stn $92 Y_{4} 4 \mathrm{~N}$, Burum, Yemen, $14^{\circ} 20^{\prime} \mathrm{N} 49^{\circ} 00^{\prime} \mathrm{E}$, 2 April 1992, RMNH D.47745. 1 s, 1 ovig. \&, paratypes, CLs $1.25,1.6 \mathrm{~mm}$, stns 92Y70 I, 92Y60J, Bir Ali, Yemen, 14 30’ N 49 03'E, 9 April 1992, QM W 21901, 21903. All specimens collected, from $<10 \mathrm{~m}$, by P. J. Hogarth.

Description. Very small pontoniine shrimps (Fig. 1a) of strongly depressed body form.

Rostrum (Fig. 1c) normally developed, compressed, acute, horizontal, extending to about 0.75 of length of proximal segment of antennular peduncle, dorsal carina well-developed, convex, with five similar acute teeth, first situated posteriorly to posterior orbital margin, intermediate spaces sparsely setose; ventral and lateral

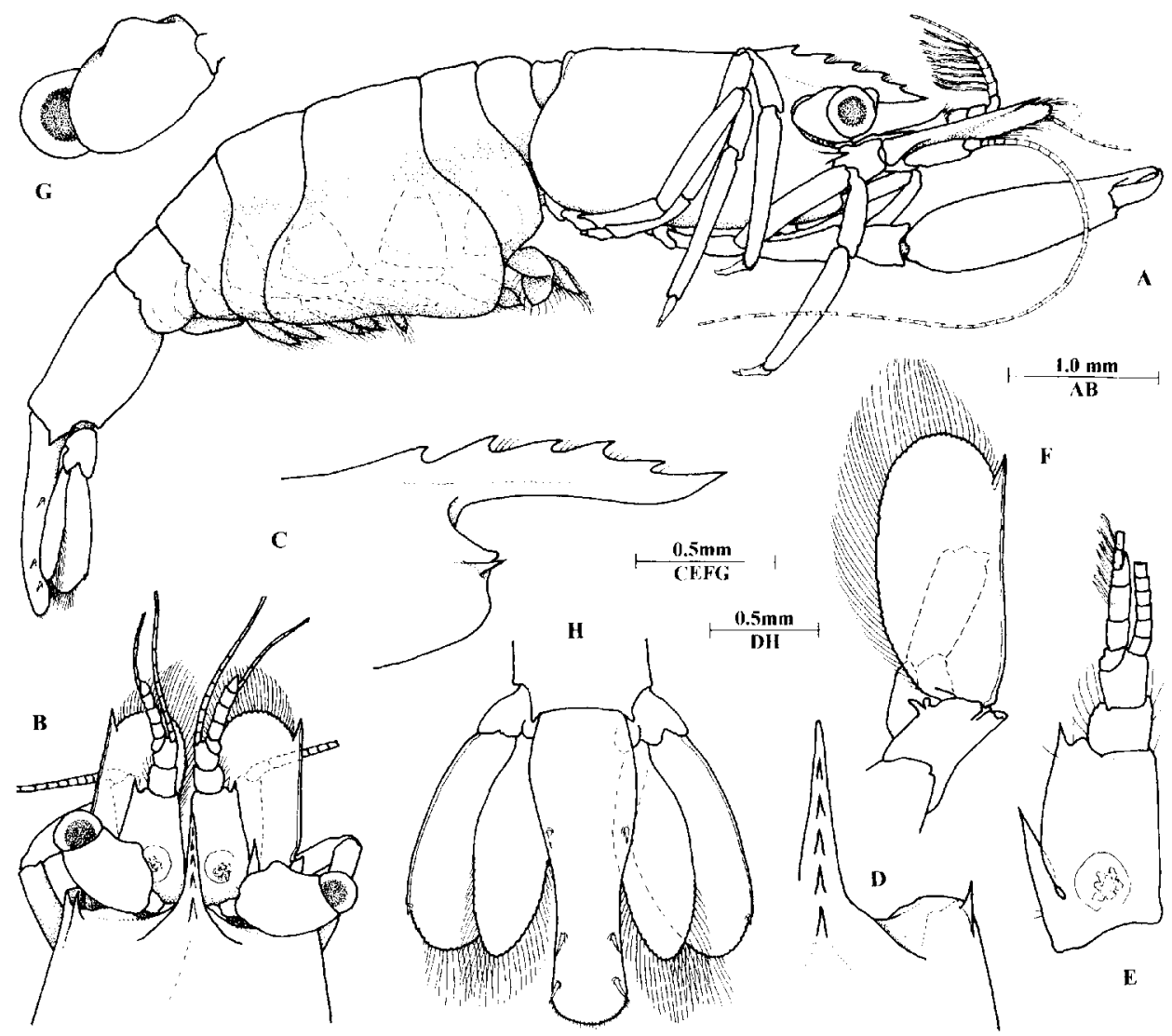

Fig. 1. Yemenicaris trullicauda gen. nov., sp. nov.: (A) ovig. female holotype, Khalf, Yemen; (B) anterior carapace, rostrum, cyes, antennae, dorsal; (C) anterior carapace and rostrum, latcral; (D) orbital region, dorsal; (E) antennule; (F) antenna; (G) eye, posterodorsal; $(\mathrm{H})$ caudal fan. $\mathrm{ABH}$, holotype, $\mathrm{C}-\mathrm{G}$, ovig. female paratype, Burum. 
StimPSON, W., 1860, Prodromus descriptionis animalium evertebratorum quae in Expeditione ad Oceanum Pacificum Septemtrionalem a Republica Federato missa, C. Ringgold et J. Rodgers Ducibus, Observavit et descripsit, Proceedings of the Academy of Natural Sciences of Philadelphia, 1860, 22-48. 


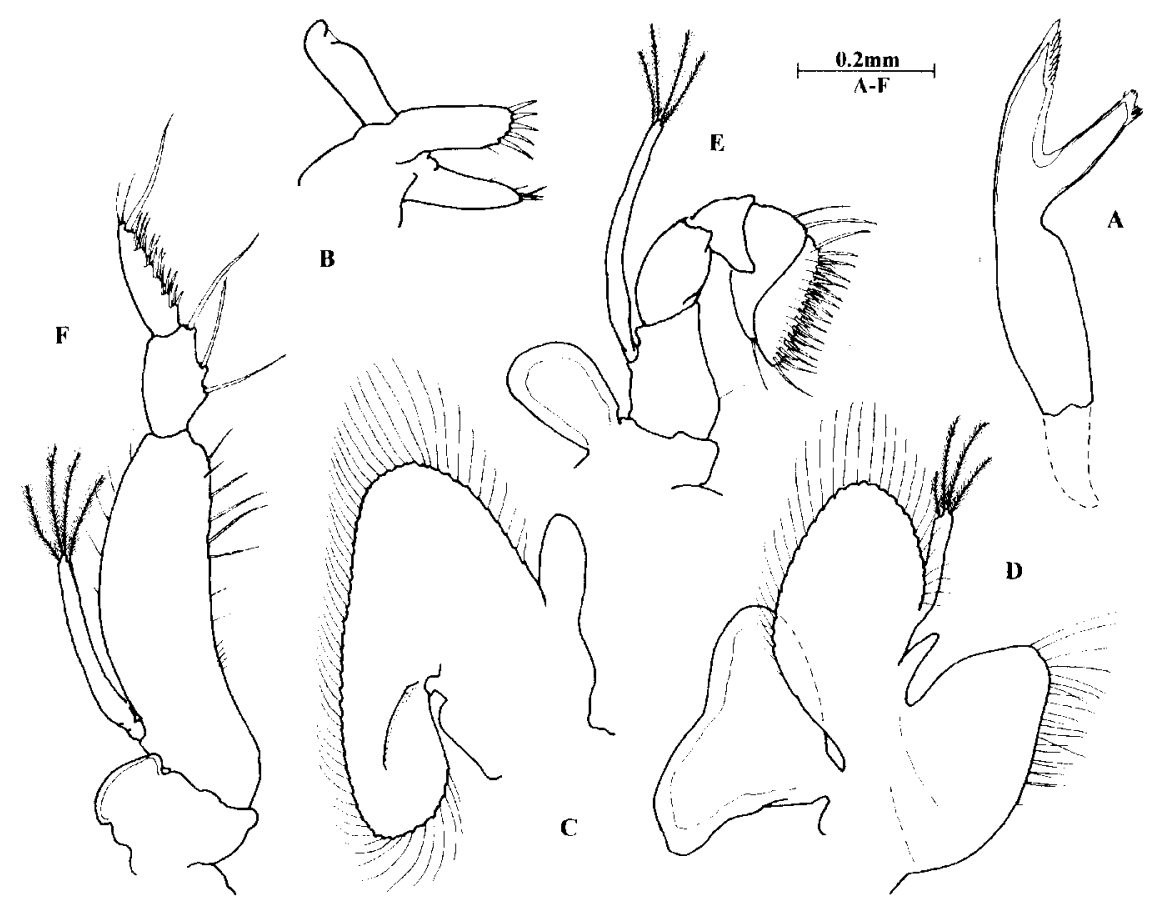

FIG. 2. Yemenicaris trullicauda gen. nov., sp. nov., paratype female, Burum: (A) mandible; (B) maxillula; (C) maxilla; (D) first maxilliped; (E) second maxilliped; ( $F$ ) third maxilliped.

carinae obsolete, ventral margin sinuous, unarmed, non-setose. Carapace (Fig. lb) depressed, smooth, glabrous, supraorbital, epigastric and hepatic spines absent; orbit obsolete, inferior orbital angle (Fig. 1d) broadly produced, antennal spine stout, submarginal, exceeding inferior orbital angle in lateral view, anterolateral angle of branchiostegite bluntly angled.

Abdomen (Fig. 1a) strongly depressed, particularly in ovigerous females, smooth, glabrous, about $2.7 \times$ longer than carapace length, third tergite not posterodorsally produced, pleura all broadly rounded, first three much enlarged in ovigerous females, curved ventromedially beneath abdomen, sixth segment about $2.6 \times$ length of fifth, $1.8 \times$ longer than deep, posterolateral angle acute, posteroventral angle reduced. Tclson (Fig. 1h) about $1.25 \times$ sixth segment length, extending far beyond distal ends of uropod rami, including marginal setae, about 0.9 of carapace length, $4.0 \times$ longer than anterior width, lateral margins proximally convex, distally concave, expanded distally, ventrally concave, scoop shaped and curved ventrally, with three pairs of small, similar dorsal spines, about 0.8 of telson length, at approximately $0.4,0.7$ and 0.9 of telson length, posterior margin (Fig. 4o) broadly arcuate, without spines, with about 30 minute simple setae.

Antennular peduncle (Fig. 1e) normal, far exceeding rostrum; proximal peduncular segment, broad, about $1.6 \times$ longer than wide, lacking ventromedial tooth, distolateral angle (Fig. 2a) slightly produced, with stout acute lateral tooth, lateral border convex, statocyst normally developed with granular statolith, stylocerite slender, acute, reaching about 0.6 of segment length, intermediate and distal segments normal, short, combined length about 0.5 of proximal segment length, upper flagellum biramous, with proximal 3-4 segments fused, short free ramus with single 

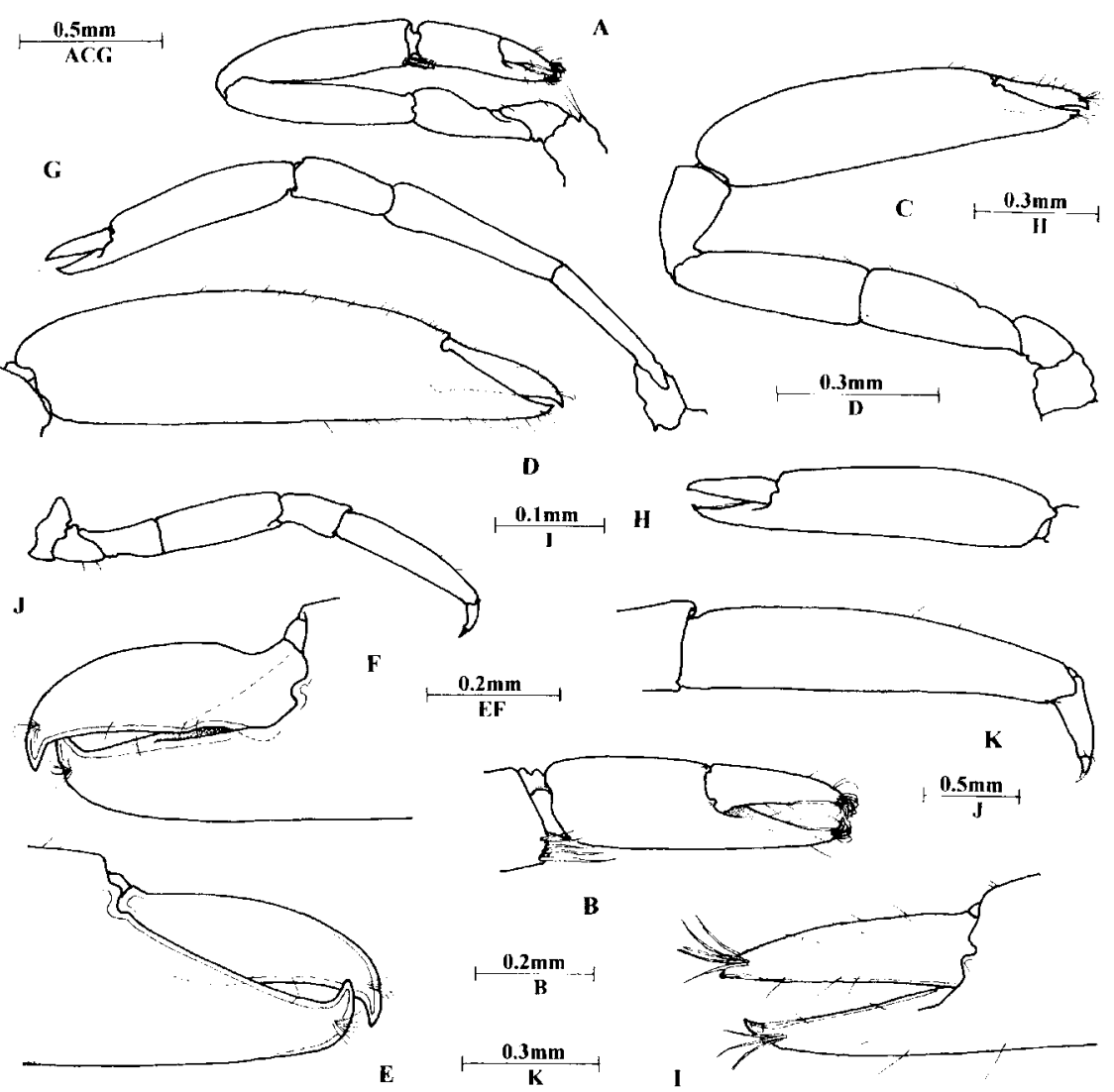

FIG. 3. Yemenicaris trullicauda gen. nov., sp. nov.: (A) first pereiopod; (B) same, chela; (C) major second pereiopod; (D) same, chela; (E) same, fingers, dorsal; (F) same, ventral; $(G)$ minor second pereiopod; $(H)$ same, chela; (I) same, fingers; $(J)$ third pereiopod; (K) same, propod and dactyl. Ovig. female paratype, Burum, ABJK. Male, Bir Ali, C - I.

segment, with 5-7 groups of aesthetascs, long ramus short, filiform, lower flagellum, short in female, about 12 short segments, very long in male, with 24 slender cylindrical segments.

Antenna (Fig. If) with basicerite unarmed distolaterally, medial border with smaller blunt ventral and longer subacute dorsal processes (Fig. 4b), carpocerite exceeding proximal segment of antennular peduncle, about $2.6 \times$ longer than distal width, reaching to about 0.6 of scaphocerite length, flagellum short, about $2 \times$ carapace length; scaphocerite well-developed, broad, about $2.0 \times$ longer than greatest width, at midlength, lateral margin feebly concave, distal border broadly rounded, distinctly exceeding stout distolateral tooth (Fig. 4c).

Eye (Fig. $1 \mathrm{~g}$ ) well-developed, length about 0.5 of carapace length, with small transverse well pigmented globular cornea, diameter about 0.2 of carapace length, without accessory pigment spot, stalk subcylindrical with conspicuous antcrodorsal protuberance, about $1.5 \times$ general width, distinctly broader than corneal diameter.

Ophthalmic somite unarmed, with small median pigment spot.

Mandible (Fig. 2a) with corpus slender, without palp; molar process (Fig. 4d) long, slender, feebly dentate distally, with small acute tecth and short spiniform 


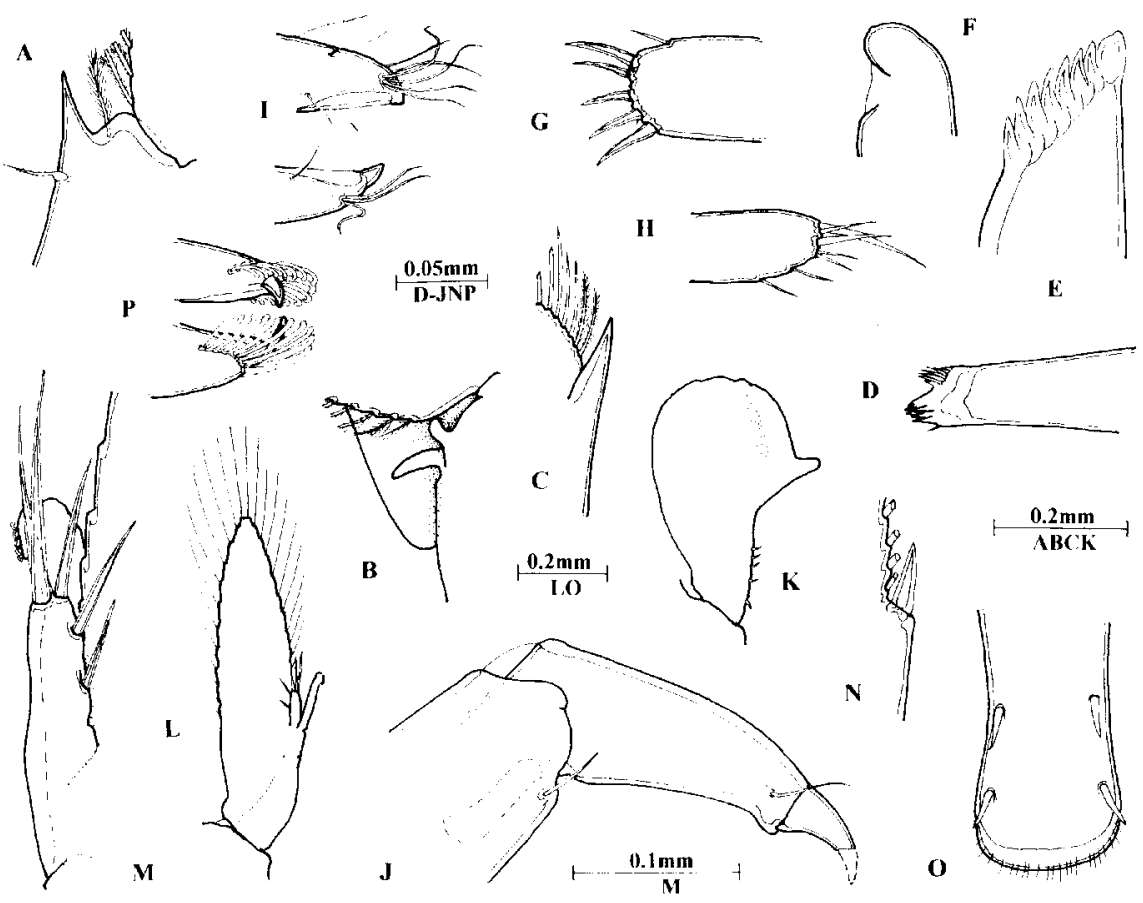

Fig. 4. Yemenicaris trullicauda gen. nov., sp. nov.: (A) antennule, distolateral tooth of proximal peduncular segment; (B) antenna, medial margin of basicerite, ventral; (C) same, distolateral tooth of scaphocerite; (D) mandible, molar process; (E) same, incisor process; ( $F$ ) maxillula, distal palp; $(G)$ same, distal end of upper lacinia; (II) same, lower lacinia; ( I minor second pereiopod, tips of lingers; ( $J$ ) third pereiopod, dactyl and distal propod; (K) lirst pleopod, endopod; (L) second pleopod; (M) same, appendix masculina and appendix interna; $(\mathrm{N})$ exopod of uropod, distolateral spine; (O) telson, posterior margin; (P) first pereiopod, tips of fingers. Ovig. female paratype, A HJNO. Male, Bir Nli, IKLM.

setae; incisor process (Fig. 4c) well-developed, slightly expanded distally, cutting edge very oblique with eight very acute teeth. Maxillula (Fig. 2b) small, palp simple, elongate, without spines or setae (Fig. 4f); upper lacinia (Fig. 4g) slender with five short simple spines; lower lacinia (Fig. 4h) more slender, tapering distally, with three short slender simple terminal spinules. Maxilla (Fig. 2c) with short simple rounded non-setose palp; endites absent, proximal medial margin convex, non-setose; scaphognathite short and broad, about $1.8 \times$ longer than wide, posterior lobe large, about 0.4 of scaphognathite length, anterior lobe angular, distally rounded. First maxilliped ( Fig. 2d) with short simple tapering non-setose palp; basal endite large, broad, sparsely setose medially, with slender, feebly setulose setae, coxal endite completcly fused to basal, medially concave, non-setose, exopod with flagellum greatly reduced, short, with four short plumose setae distally, caridean lobe large, oval; epipod large, triangular, slightly bilobed. Second maxilliped (Fig. 2e) with normal endopod, dactylar segment broad, medial margin with dorsal row of long serrulate spines and ventral row of shorter similar spines, propod not distomedially produced, sparsely spinose, basis feebly excavate medially, exopod with slender flagellum with four plumose distal setae, coxa not medially produced, with suboval epipod, without podobranch. Third maxilliped (Fig. 2f) extending to just beyond 
distal margin of statocyst; endopod with ischiomerus completely fused to basis, combined segment about $3.5 \times$ longer than central width, sides subparallel, lateral margin sparsely setose, medial border concave, with few simple spiniform setae distally, exopod with slender flagellum with four plumose distal setae, penultimate segment short, about 0.28 of antepenultimate segment length, $2 \times$ as long as wide, with three long simple spines medially, terminal segment about $0 \cdot 31$ of antepenultimate segment length, $3.5 \times$ longer than maximal width, tapering distally with single long simple preterminal spine, medial margin with five transverse rows of short serrulate spines, exopod with slender flagellum with four plumose distal setae, coxa feebly produced medially, with small oval lateral plate, without arthrobranchs.

Fourth thoracic sternite without median process; posterior sternites subtriangular, broadening posteriorly, unarmed.

First pereiopod (Fig. 3a) slender, exceeding scaphocerite by chela; chela (Fig. 3b) with palm subcylindrical, slightly compressed, about $1.7 \times$ longer than central depth, with few serrulate setae proximoventrally, fingers stout, about 0.8 of palm length, tapering distally to stout, articulated hooked tips, surrounded by palisade of stout recurved setae with blunt hooked tips (Fig. 4p), proximal halves of cutting edges entire, distal halves with narrow entire lamina; carpus about $1.5 \times$ palm length, robust, $4.0 \times$ longer than central depth, with sparse serrulate setae distoventrally; merus about 0.95 of carpal length, $4.6 \times$ longer than central width; ischium about 0.6 of carpal length; basis and coxa normal, coxa with small setose ventromedial process.

Second pereiopods similar, markedly unequal. Major second pereiopod (Fig. 3c) with chela (Fig. 3d) subequal to carapace length, palm smooth, very sparsely setose, subcylindrical, slightly swollen and compressed, about $3 \cdot 2 \times$ longer than central width, tapering slightly distally, dactyl (Fig. 3f) about 0.27 of palm length, extending well beyond fixed finger, $3.4 \times$ longer than central depth, with strongly hooked tip, cutting edge entire, blunt, opposing into groove on fixed finger, fixed finger (Fig. 3e) about $1.5 \times$ longer than dorsal width, grooved for reception of dactylus proximally, both cutting edges entire, ventral edge lower than dorsal, tip strongly hooked; carpus, merus and ischium robust, carpus about 0.35 of palm length, robust, $2 \times$ as long as central width, slightly expanded distally, unarmed; merus about 0.6 of palm length, $1.7 \times$ carpus length, $3.0 \times$ longer that proximal width, unarmed; ischium about 0.9 of merus length, $2.7 \times$ longer than distal width, unarmed; basis and coxa stout, without special features. Minor second pereiopod (Fig. 3g) with chela (Fig. 3h) about 0.6 of carapace length, palm smooth, subcylindrical, slightly compressed, about $3.7 \times$ longer than proximal width, tapering slightly distally, dactyl (Fig. 3i) about 0.33 of palm length, extending slightly beyond fixed finger, $3.5 \times$ longer than proximal depth, without hooked tip (Fig. $4 \mathrm{i}$ ), cutting edge straight, entire, blunt, opposing into feeble groove on fixed finger, fixed finger (Fig. 3i) about $3.25 \times$ longer than proximal width, tip feebly hooked (Fig. 4i), articulated, cutting edge straight, entire, blunt; carpus, merus and ischium more slender, carpus about 0.5 of palm length, 2.2 as long as distal width, slightly expanded distally, unarmed; merus about 0.95 of palm length, $1.7 \times$ carpus length, $3.8 \times$ longer that distal width, unarmed; ischium slender, about 0.9 of merus length, $2.7 \times$ longer than distal width, unarmed; basis and coxa stout, without special features.

Ambulatory pereiopods robust. Third pereiopod (Fig. 3j) exceeding carpocerite by propod and dactyl, with dactyl (Fig. 4j) slender, simple, compressed, unguis distinctly demarcated from corpus, robust, strongly curved, about twice as long as 
basal width, corpus $2 \cdot 2 \times$ longer than basal width, dorsal border convex, non-setose, ventral border concave, blunt, with small distal protuberance, broader than basal width of unguis, distal width about 0.4 of basal width, with single sensory seta distolaterally; propod (Fig. 3k) about 0.75 of carapace length, $4.0 \times$ longer than dactyl, $5.0 \times$ longer than proximal width, tapering distally, sparsely setose, with single very slender distoventral spine; carpus 2.4 of propod length $1.7 \times$ longer than distal width, unarmed; merus 0.8 of propod length, $3.0 \times$ longer than central width, unarmed; ischium 0.5 of propod length, $2.2 \times$ longer than distal width; basis and coxa without special features. Fourth and fifth pereiopods similar to third, fourth propod 0.8 of third propod length, fifth subequal to third propod length, fifth propod without transverse rows of cleaning setae distally.

Pleopods normal, rami broad in female, reflected ventrally; endopod of male first pleopod (Fig. 4k) with distal half broadly expanded, distal border semicircular, with small subacute process medially; proximal half of medial margin with five small curved simple spinules, distal and lateral margins non-setose; endopod of second pleopod (Fig. 41 ) with appendices (Fig. $4 \mathrm{~m}$ ) at about 0.3 of length, appendix masculina short, stout, $4 \cdot 0 \times$ longer than wide, about $0 \cdot 1$ of endopod length, with three simple terminal spines, longest slightly shorter than corpus length, two similar shorter distomedial spines, appendix interna exceeds appendix masculina, with few distal cincinnili.

Uropods (Fig. 1h) with protopodite posterolaterally blunt, rami extending to about 0.7 of telson length; exopod about twice as long as wide, lateral margin entire, convex with small mobile distal spinule only (Fig. 4n), dieresis obsolete, endopod subequal to exopod length, $3 \cdot 0 \times$ longer than central width.

Measurements (in $\mathrm{mm}$ ). Ovigerous female holotype: postorbital carapace length, 1.67: carapace and rostrum, 2.37: total body length $c a 7 \cdot 2$; second pereiopod, major chela, 1.75; minor chela, 1.02; length of ovum, 0.55 .

Colouration. No data.

Host. Holotype from Stylophora sp., paratypes from Pocillopora pistillata Esper and Stylophora sp. [Coelenterata: Scleractinia].

Etymology. From trulla (Latin), a scoop, and cauda (Latin), a tail, a reference to the shape of the telson.

Associated fauna. Pontoniine shrimps also collected from the same localities included: Palaemonella rotumana (Borradaile, 1898), Jocaste lucina (Nobili, 1901), Harpiliopsis beaupresii (Audouin, 1826), H. depressa (Stimpson, 1860), Periclimenaeus arabicus (Calman, 1939), Periclimenes grandis (Stimpson, 1860), P. obscurus Kemp, 1922, Coralliocaris viridis Bruce, 1974 and Onycocaris sp. Periclimenes obscurus, Periclimenaeus arabicus, Coralliocaris viridis and Onycocaris $\mathrm{sp}$. are species that have not been previously reported from Yemen. The holotype also shared its host with some crabs, Trapezia cymodoce and T. tigrina, and Cymo ?quadrilobatus (det. P. J. Hogarth).

Remarks. The telson of Yemenicaris trullicauda is clearly unique and bears no resemblance to that of any other palaemonid shrimp. The ambulatory dactyl is also unusual, although less remarkable, and is probably also unique, with the small distal enlargement of the corpus giving the ventral border a characteristic biconcave appearance unlike that of any other species. This dactyl, in combination with the spinulation of the distal propod, would enable an incomplete specimen to be readily identified. The species is also noteworthy for its very small size, the largest specimen having a carapace length of only $1.67 \mathrm{~mm}$ and total body length of $7.2 \mathrm{~mm}$. The 
species is therefore one of the smallest pontoniine shrimp species. Ovigerous females of Fennera chacei Holthuis, also an associate of Pocillopora corals, have a total body length of up to $6 \mathrm{~mm}$ (Holthuis, 1951) and are therefore slightly smaller. Tectopontonia maziwiae Bruce, an associate of Acropora corals, is a little larger, with a body length of $8 \mathrm{~mm}$ (Bruce, 1973). On account of its small size the ovigerous females of Yemenicaris trullicauda carry only a few ova, about 4-6, (although some may have been lost). The ova are of normal pontoniine size. The sexual dimorphism in the lower antennular flagella is also noteworthy and has not been previously in the Pontoniinae and the absence of a ventromedial tooth on the proximal segment of the antennular peduncle is also unusual.

\section{Acknowledgements}

I am most grateful to Dr Peter Hogarth for the opportunity to report upon this small collection of Yemeni shrimp. The assistance provided to the 1992 Yemen Expedition by the Rector and staff, especially Dr Abdul Majeid Haddas, of the University of Sana'a, is much appreciated.

\section{References}

Audouin, V., 1826, Éxplication sommaire des planches de Crustacés de l'Égypte et de la Syrie, publiées par Jules-Cesar Savigny, membre de l'Institute: offrant un exposé des caractères naturelles des genres avec la distinction des espèces. Description de l'Égypte ou receuil des observations et des recherches qui on été faites en Égypte pendant l'expédition de l'armée francaise, Histoire naturelle, 1(4), 77-98.

Borradaile, L. A., 1898, A revision of the Pontoniidae, Annals and Magazine of Natural History, 2(7), 376-391.

BRUCE, A. J., 1969, Observations upon the host-specificity and distribution of Jocaste japonica (Ortmann) and Jocaste lucina (Nobili) (Decapoda Natantia, Pontoniinae), Crustaceana, 17(3), 298-302, figs 1-2.

Bruce, A. J., 1971, Pontoniinid shrimps from the ninth cruise of the R/V Anton Bruun, IIOE, 1964: I. Palaemonella Dana and Periclimenes Costa, Smithsonian Contributions to Zoology, 82, 1-13, fig. 1.

Bruce, A. J., 1973, Notes on some Indo-Pacific Pontoniinac, XXIII. Tectopontonia maziwiae gen. nov., sp. nov., a new coral associate from Tanganyika (Decapoda Palaemonidae), Crustaceana, 24(2), 169-180, figs 1-4.

Bruce, A. J., 1974, Coralliocaris viridis sp. nov., a preliminary note (Decapoda Natantia, Pontoniinae), Crustaceana, 26(2), 222-224, fig. 1.

Bruce, A. J., 1978, Pontoniinid shrimps from the ninth cruise of the R/V Anton Bruun; I.I.O.E. 1964, II. The remaining genera, Bulletin of Marine Science, 28(1), 118-136, figs $\mathbf{1}-3$.

Calman, W. T., 1939, Crustacea: Caridea, Scientific Reports of the John Murray Expedition, 6, 183-224, figs $1-8$.

Forsskål, P., 1775, Descriptiones Animalium, Avium, Amphibiorum, Piscium, Insectorum, Vermium; quae in Itinere Orientali Observavit, pages $19+$ xxxii +164 pages. (Haunia: Heineck et Faber), 1 19, i-xxxii, 1-164.

Holtuus, L. B., 1951, A general revision of the Palaemonidae (Crustacea Decapoda Natantia) of the Americas. I. The Subfamilies Euryrhynchinac and Pontoniinac, Allan Hancock Foundation Publication, Occasional Paper, 11, 1-332, pls 1-63.

Holthuis, L. B., 1986, Some Pontoniinae (Crustacea:Decapoda:Palaemonidae) from southern Oman, Zoologische Verhandelingen, Leiden, 60(17), 263-272, figs 1-2.

KemP, S., 1922, Notes on Crustacea Decapoda in the Indian Museum. XV. Pontoniinae, Records of the Indian Museum, 24, 113-288, figs 1-105, pls 39.

Nobis, G., 1906, Faune Carcinologique de la Mer Rouge. Décapodes et Stomatopodes, Annales des Sciences Naturelles, Paris, Zoologie, 4(9), 1-347, text figs 1-12, pls 1-11. 